\title{
Marked compositional changes in harvestmen assemblages in Amazonian forest islands induced by a mega dam
}

\author{
Ana Lúcia Tourinho ${ }^{1 *}$, Maíra Benchimol ${ }^{2}$, Willians Porto ${ }^{3}$, Carlos A. Peres ${ }^{4,5}$ \& \\ Danielle Storck-Tonon ${ }^{6}$
}

1. Programa de Pós-Graduação em Ciências Ambientais, Universidade Federal do Mato

Grosso, Instituto de Ciências Naturais, Humanas e Sociais, Núcleo de Estudos da Biodiversidade da Amazônia Mato-Grossense (NEBAM), Av. Alexandre Ferronato, 1200, Setor Industrial, CEP: 78577-267, Sinop, MT, Brazil.

2. Laboratório de Ecologia Aplicada à Conservação, Universidade Estadual de Santa Cruz, Rodovia Jorge Amado km 16, CEP: $45662-900$ Ilhéus, BA, Brazil.

3. División de Aracnología, Museo Argentino de Ciencias Naturales-CONICET, Av. Ángel Gallardo 470, C1405DJR Buenos Aires, Argentina.

4. School Environmental Sciences, University of East Anglia, Norwich NR47TJ, UK

5. Departamento de Sistemática e Ecologia, Universidade Federal da Paraíba, João

Pessoa, CEP 58051-900, Brazil.

6. Programa de Pós-Graduação em Ambiente e Sistemas de Produção Agrícola, Universidade do Estado de Mato Grosso, Rod. MT 358, km 7 - Jardim Aeroporto. CEP: 78300-000, Tangará da Serra, MT, Brazil.

*Corresponding author: Ana Lúcia Tourinho, <amtourinho@gmail.com>

Running Title: Mega dam changes harvestmen assemblages

Key words: Conservation biology, landscape ecology, habitat fragmentation, hydroelectric dams, environmental quality, indicator species 


\begin{abstract}
1. Mega hydroelectric dams have become one of the main drivers of habitat loss in tropical forests, converting large tracts of pristine forests into isolated forest islands. Understanding how biodiversity cope with landscape modification in these archipelagic landscapes is of paramount importance to assess the environmental consequences of dam infrastructure and propose mitigation actions for biodiversity conservation. In this context, harvestmen (Opiliones, Arachnida) comprise an excellent indicator taxon of habitat quality, given their high sensitivity to desiccation and microclimatic change.
\end{abstract}

2. We investigate the effects of landscape change induced by a mega hydropower dam on forest harvestmen species richness, abundance and composition within the Balbina Hydroelectric Dam, Central Brazilian Amazon. We sampled 20 islands and five mainland continuous forests, relating our biological response variables to local, patch and landscape scale metrics.

3. Although unexpectedly species richness was unaffected by any local, patch and landscape variables, species composition and abundance were differentially affected by a set of predictor variables at different scales. Forest cover and fallen woody stems were significant predictors of patterns of species composition, whereas vegetation density, forest cover, island area, abundance of palm trees, and fallen woody stems best explained harvestmen abundance.

4. Our results indicate that both islands embedded within greater and lower amount of forest cover are important to ensure high diversity of harvestmen. We recommend retaining large forest habitat patches surrounded by a large amount of forest cover to minimize forest disturbance effects and enhance long-term persistence of harvestmen sensitive species in large hydroelectric dams.

\title{
Introduction
}

Hydroelectric dams have been posed as a major new villain for Amazonian rainforest and freshwater ecosystems, severely inducing the widespread habitat loss and wholesale local species extinctions (Benchimol \& Peres, 2015a; Bobrowiec \& Tavares, 2017, Lees et al., 2016). The Amazon basin accounts for $18 \%$ of global scale river discharge (Dai \& Trenberth, 2002), so it is not surprising that this region has rapidly 
become a major target for hydropower development; in addition to 191 existing dams, 246 additional dams may be built across the whole Amazon Basin in the next few decades (Lees et al. 2016). Indeed, more than 1,300,00 ha of forest has already been flooded by operational dams in the Brazilian Amazon alone (ECOA, 2018).

Although mega-dam infrastructure projects have often been referred to as 'green energy' sources (renewable energy resources that provide the highest environmental benefits) (Gibson et al., 2017), several studies have shown the pervasive social and environmental impacts of large dams. From local communities (Esselman \& Opperman, 2010, Fearnside, 2016) to fluvial hydrology (Nilsson et al., 2005), large dams affect indigenous communities by flooding their territories, and increasing greenhouse gas emissions (Almeida et al., 2010). They also drive local extinctions of both aquatic (Alho, 2011; Liermann et al., 2012; Palmeirim et al., 2014) and terrestrial fauna and flora (Terborgh et al., 1997; Benchimol \& Venticinque, 2014, Benchimol \& Peres, 2015a,b,c). However, few studies have assessed the effects of large dams on terrestrial invertebrates, despite their immense importance for forest nutrient cycling and ecosystem services (Storck-Tonon \& Peres, 2017, Carvalho et al., 2012). For instance, a study has shown that most orchid bee species are driven to local extinction after 26 years of insularization within a mega dam in central Brazilian Amazonia, with potential effects on pollination (Storck-Tonon \& Peres, 2017).

Several groups of arthropods can be described as effective bioindicators, providing valuable information on environmental quality at both small and large scales on the basis of rapid surveys, enabling their efficient inclusion in environmental licensing studies prior to development projects (Maleque et al., 2006, Melo et al., 2015). Additionally, arthropods play an important role in many key processes influencing ecosystem cycling of carbon and other nutrients, and modulating the amount and quality of resources entering the detrital food web (Yang \& Gratton, 2014). These processes may occur via direct or indirect pathways mediated through species interactions via plants and soil microbes, integrating community-level interactions with ecosystem processes. Arachnids are mostly generalist predators, and are often more dependent on the physical structure of microhabitats than on prey availability (Villanueva-Bonilla et al., 2017). Most harvestmen species (Opiliones, Arachnida) inhabit humid habitats; indeed, they are physiologically dependent of humid 
environments, due to their high susceptibility to desiccation, nocturnal activity and low vagility (Pinto-da-Rocha et al., 2007).

Despite the significant ecological importance of harvestmen (Fig. 2), serving as excellent predictors of environmental quality given their rapid responses to habitat change and fragmentation (Bragagnolo et al., 2007, Černecká et al., 2017), this charismatic taxonomic group remains poorly investigated in tropical fragmented forest landscapes. Considering that fragmentation is a landscape-scale process (Fahrig, 2003), studies assessing the responses of harvestmen communities to forest fragmentation should explicitly consider the influence of landscape variables. Under the island biogeography paradigm (MacArthur \& Wilson, 1967), fragment size and isolation are frequently hailed as primary determinants of species richness in remaining habitat patches. Yet several studies have clearly emphasized the importance of also considering the spatial arrangement of forest fragments and habitat quality. For instance, the percentage of surrounding habitat within the landscape has been widely considered as a good predictor of species diversity for several vertebrate and floristic groups (Andrén, 1994; Morante-Filho et al., 2015; Benchimol et al., 2017), and the dominant role of habitat amount has been suggested when species richness is measured at sample sites (Fahrig, 2013; but see Bueno \& Peres 2019). Thus, combining different patch and landscape metrics are likely to provide a better understanding on the effects of habitat fragmentation on the diversity patterns of harvestmen assemblages.

Additionally, patterns of diversity in harvestmen assemblages are highly correlated with vegetation structure at meso and local scales, and are especially responsive to the presence of large old trees and palms in Amazonian forests (Colmenares et al., 2016; Tourinho et al., 2014, 2018, Porto et al., 2016). This occurs because palms increase habitat complexity at ground level, as a consequence of the fallen litter trapped within their leaves (Vasconcelos, 1990, Franken et al., 2013). Therefore, both palm and non-palm trees are directly responsible for the quality, depth and decomposition of the soil leaf-litter layer, which are a key microhabitat components affecting assemblages of small-bodied harvestmen species and other invertebrates (Tarli et al., 2014, Colmenares et al., 2016, Porto et al. 2016).

Although few studies have shown the negative impacts of fragmented forest habitats on harvestmen assemblages in temperate forests (Černecká et al., 2017, Mihál 
\& Černecká, 2017), only one study to date -- conducted in forest patches embedded within heterogeneous vegetation matrices in the Brazilian Atlantic forest -- has assessed the effects of forest fragmentation on harvestmen within a tropical forest landscape (Bragagnolo, et al. 2007). In this study, harvestmen assemblages were more clearly structured by forest quality and size than other arthropod taxa, suggesting that they are good community-wide indicators of intermediate-level disturbances and can be used as a robust model to monitor tropical forest disturbance. However, we still lack information on how this key taxonomic group is affected by habitat insularization, with archipelagic ecosystems formed in the aftermath of rising floodwaters induced by large dams providing a unique natural experiment in this context.

Here, we assessed the degree to which forest fragmentation induced by a mega hydroelectric dam affects harvestmen assemblages in the Brazilian Amazon. We conducted sampling surveys at five mainland continuous forest sites and 20 widely distributed forest islands differing in size, shape and degree of isolation within the 443,772-hectares Balbina Hydroelectric Dam. Specifically, we investigate (1) the overall patterns of harvestmen structure in insular forest environments; and (2) the potential effect of landscape features and habitat structure on harvestmen assemblages. For this, we firstly investigated the area and isolation effects following the equilibrium theory of island biogeography, and then examined the degree to which patch and landscape metrics and local habitat variables can predict harvestmen species richness, abundance and composition across forest islands.

\section{Materials and Methods}

\section{Study site}

We conducted this research at the Balbina Hydroelectric Reservoir landscape - BHR $\left(1^{\circ} 48^{\prime} \mathrm{S} ; 59^{\circ} 29^{\prime} \mathrm{W}\right)$, located in the state of Amazonas, central Brazilian Amazonia. The Balbina Dam is a large man-made reservoir that was formed in 1987 by the damming of the Uatumã river, aiming to supply power to the growing capital city of Manaus. An area of 312,900 ha was inundated, resulting in the creation of 3,546 islands ranging in size from $<1$ to 4,878 ha. Most islands are covered by primary sub-montane dense forests, and are surrounded by open-water and dead trees that rise above the water level; the mean water column depth range from $7.4 \mathrm{~m}$ (in most of the reservoir) to $30 \mathrm{~m}$ (in the 
former river channel; Eletronorte, 1997). Mean annual temperature is $28^{\circ} \mathrm{C}$ and the mean annual precipitation is $2376 \mathrm{~mm}$. A large tract of pristine continuous forest sites surrounds the Balbina archipelagic landscape, and share similar floristic composition, fauna, climate and topography (Benchimol \& Peres, 2015a,c). In 1990, part of the archipelago and an extensive tract of neighbouring pristine forest became protected by the creation of the $\sim 940,358$-ha Uatumã Biological Reserve, the largest Biological Reserve in Brazil. Although islands are unaffected by logging and hunting pressure, several islands experienced ephemeral understorey fires during the El Niño drought of late-1997 (Benchimol \& Peres, 2015a).

\section{Study Design}

We selected 20 islands using two cloudless georeferenced Landsat ETM+ scenes. Additionally, we surveyed five continuous ('pseudo-control') forest sites located in the southernmost part of the Uatumã Reserve, within a permanent study grid of the PPBio (Brazilian Biodiversity Research Program, Fig. 1). Islands were selected on the basis of their size, shape, isolation and spatial distribution, keeping a minimum distance of $1 \mathrm{~km}$ from one another (Fig. 1). Likewise, each continuous forest site in the mainland was also spaced by $1 \mathrm{~km}$ from each other. Island area ranged from 11.8 to 218.5 ha (mean \pm $\mathrm{SD}=91.5 \pm 69.7 \mathrm{ha}$ ), and ranged widely in isolation distances [to the nearest mainland continuous forest] from $10 \mathrm{~m}$ to 9,000 $\mathrm{m}$ (mean $\pm \mathrm{SD}=3,220 \pm 2,648 \mathrm{~m}$ ).

\section{Harvestmen sampling}

Between 2006 and 2008, we systematically sampled harvestmen assemblages (Fig. 2) using four $300-\mathrm{m}^{2}$ transects $(30 \mathrm{~m} \times 10 \mathrm{~m})$ at each forest site, separated by $30 \mathrm{~m}$, totalling 1,200 $\mathrm{m}^{2}$ of transect area per site (see Tourinho et al., 2014, 2018, Porto et al., 2016). To avoid edge effects on islands, transects were established at least $250 \mathrm{~m}$ from the nearest forest edge. Each plot was surveyed using both an active nocturnal search method (Sørensen et al., 2002; Pinto-da-Rocha \& Bonaldo, 2006; Resende et al., 2012) and diurnal beating tray surveys. Nocturnal searchers were performed by one collector for 1 hour, during which all harvestmen (and other arachnids) encountered on the forest 
floor to a height of $2 \mathrm{~m}$, on tree trunks and other vegetation were captured. Beating tray surveys were conducted during daylight hours, by one collector for $1 \mathrm{~h}$, during which shrubs up to $3 \mathrm{~m}$ in height were struck 20 times with a wooden stick. We used a $1-\mathrm{m}^{2}$ white fabric wooden frame positioned underneath the shrubs to capture any fallen harvestmen.

All individuals collected were subsequently identified at the lowest taxonomic level by experts on harvestmen taxonomy (Ana Lúcia Tourinho, Pío Colmenares \& Willians Porto). For this, we examined the external morphology of individual specimens under a stereomicroscope, which were compared with original descriptions provided in the literature (Pinto-da-Rocha, 1994, 1996, 1997, 2004; Kury, 2003), type specimens, and photographs of type specimens. We excluded from the dataset nymphs and females, which have ambiguous morphology, because they cannot be assigned to any genus or species level. In the case of species groups with a very conservative external morphology and/or poorly understood taxonomy (e.g. Cosmetidae, Sclerosomatidae, Zalmoxidae) we also examined their male genitalia to improve species delimitation, following Acosta et al. (2007). All specimens collected were preserved in $70 \%$ ethanol and deposited in the Invertebrate Collection of the Instituto Nacional de Pesquisas da Amazônia, Manaus, Amazonas, Brazil, under curator, Dr Célio Magalhães.

\section{Landscape and habitat variables}

We used RapidEye ${ }^{\odot}$ high-resolution (5-m pixel) imagery for the entire Balbina archipelago to quantify landscape structure variables at the patch and landscape-scales, associated with each of surveyed forest site. At the patch scale, we obtained the total island area in hectares $\left(\log _{10} \mathrm{x}\right.$; 'area'); the isolation distance from each island to the nearest mainland (' $D_{\text {mainland') }}$; and the island shape ('shape') by dividing the total island area by the total island perimeter using ArcMap (ESRI, 2016). At the landscape scale, we estimated the total amount of forest cover ('cover') within a specified radius, and modified the proximity index of McGarigal et al., (2012) by considering the total size of any land mass within the buffer, rather than excluding land areas outside the buffer within patches encompassed by the buffer ('prox'). We considered multiple buffers $(250 \mathrm{~m}, 500 \mathrm{~m}$ and $1000 \mathrm{~m})$ outside the perimeter of each focal island and mainland forest sites for landscape-scale analyses. 
We selected variables at local scale that were previously documented and/or tested to influence harvestmen assemblages. In this regard it was demonstrated that harvestmen assemblages use trees as refuges when disturbed, but only in sites with higher harvestmen diversity in the ground/litter microhabitat (Proud et al., 2012). Recent research also offered evidence for a relationship between number of palm trees and harvestmen assemblage composition in upland Amazonian forest (Tourinho et al., 2014; Colmenares et al., 2016; Porto et al., 2016). In previous studies in Amazon upland forests, most abundant harvestmen species were found mostly in trees (Colmenares Tourinho et al., 2014; Porto et al., 2016), being especially common in the accumulated litter at the base of the fronds in stemless and arborescent palms. Fallen logs, roots, termite nests, and suspended litter at the base of trees and palm leaves are the habitats favored by harvestmen, providing ideal microclimatic conditions of humidity and temperature for their development (Mestre \& Pinto-da-Rocha, 2004; Curtis \& Machado, 2007; Curtis, 2007; Proud et al., 2012). We also obtained at local scale the following variables the litter depth ('litdepth'), the number of trees ('trees'), the total number of palm trees ('palms') and the number of fallen woody stems ('fallen'). 'Fallen' considered down wood and does not include arborescent palm left bracts all of which were used here as proxies of vegetation habitat structure available to harvestmen (Colmenares et al. 2016). For this, we mapped all non-palm and palm trees with a diameter at breast height $(\mathrm{DBH})>30 \mathrm{~cm}$ within each $300-\mathrm{m}^{2}$ transect (Table 1). We also mapped all fallen stems within each plot. At every $5 \mathrm{~m}$ along the long axis of the transects, a measurement of litter depth was taken. These measurements consisted of forcing a wooden stick $0.5 \mathrm{~cm}$ in diameter into the litter until it reached the soil and noting the height (in $\mathrm{cm}$ ) above ground to the top layer of litter.

\section{Data analysis}

We pooled data from the four sampled transects on each island and each mainland site, each of which were used as a sampling unit. We firstly compared the coefficient of determination $\left(\mathrm{R}^{2}\right)$ from regression analysis of each community attribute investigated (i.e., species richness, overall abundance and species composition) for each forest cover radius (i.e., $250 \mathrm{~m}, 500 \mathrm{~m}, 1000 \mathrm{~m}$ ) to determine which radial buffer best explained diversity patterns. The highest $\mathrm{R}^{2}$ values were obtained at $1000 \mathrm{~m}$ radius (see 
Table S1), so we used this buffer size for all subsequently analyses. We thus performed a Pearson correlation test using all landscape and habitat variables, excluding variables that were highly correlated $(r \geq 0.50)$ from the analysis, resulting in five habitat and landscape variables maintained in the global models: area, litter depth, number of palm trees, number of fallen woody stems, and forest cover. Among the correlated variables we have chosen the variables that were previously documented and/or tested to have a strong influence in harvestmen assemblages.

To assess differences in harvestmen assemblage structure among the habitat types (islands and mainland) we performed permutational multivariate analysis of variance (PERMANOVA) using the landscape and habitat variables. We used a multiple regression on distance matrices analysis (MRM) to analyse changes in species composition and test for spatial correlation between all surveyed sites, this analysis is similar to partial Mantel tests and was used to examine the levels of correlation and the spatial independence between the dependent distance matrix and the independent explanatory distance matrices. For that we used the abundance matrix of each species obtained within the transects, then the longitude and latitude matrix to create a geographic distance matrix and all the landscape and habitat variables cited above to create the explanatory variables distance matrices that were used to perform the MRM.

Following the theory of island biogeography (MacArthur \& Wilson 1967), we first examined the potential effects of island size $(\log (\mathrm{x}+1))$ and isolation $\left(D_{\text {mainland }}\right)$ on harvestmen species richness, abundance and composition using linear regression. For the latter, we reduced the data dimensionality using NMDS ordinations based on two axes, considering both the Jaccard (presence/absence) and Bray-Curtis (abundance) similarity values, and used the first axis as a predictor of species composition.

We further performed Generalized Linear Models (GLMs) to examine the relationship between harvestmen species richness, abundance and composition $\left(\mathrm{NMDS}_{1}\right)$ of islands and the explanatory variables. Multicollinearity among these variables was tested using Variation Inflation Factors (VIF) (Domman et al. 2013) using the 'HH' package (Heiberger, 2016), deleting the least moderately redundant or collinear variables (VIF > 6). We used Poisson, Gaussian and quasi-Poisson error structures for GLMs of species richness, composition, and abundance, respectively. For all response variables, the global model included all non-collinear environmental 
variables. We thus ran all possible combinations of subsets in addition to the null model using the 'MuMIn' package (Barton, 2018) and retained all models that differed by $\Delta$ AIC $\leq 2.00$ (Burnham \& Anderson 2002). All analyses were performed within the $\mathrm{R}$ 3.3.1 environment (R Core Team 2016) and RStudio Team (2016).

\section{Results}

A total of 783 harvestmen representing 31 species, 22 genera and 9 families were collected across all sampling sites throughout the BHR (Table 3). These ranged along the size spectrum from the small-bodied Fissiphalliidae, Zalmoxidae and Stygnomatidae $(2.00 \pm 2.50 \mathrm{~mm})$ to the large-bodied Stygnidae species of Protimesius $(4.95 \pm 10.85$ $\mathrm{mm}$ ) (Fig. 2). The number of species co-occurring within any given island or continuous forest site ranged from 1 to 20 (mean $\pm \mathrm{SD}=6.25 \pm 4.14$ ) species. The families containing the largest numbers of species recorded were Stygnidae (9), Sclerosomatidae (6), Manaosbiidae (4), and Cosmetidae (4) (Table 3), whereas the most abundant families were Stygnidae (209) and Manaosbiidae (202). Nine species were collected exclusively on islands, 14 were exclusively collected at mainland sites, and nine in both islands and mainland sites (Fig. 5, Table 3). The families with largest number of species on islands were Stygnidae (7) and Zalmoxidae (3), whereas the Sclerosomatidae (6) and Stygnidae (5) were the most speciouse families in the mainland. All Sclerosomatidae (194 individuals, 6 species) were exclusively restricted to mainland sites (Fig. 5). The number of species per island was much lower than recorded at mainland forest sites. Indeed, $55 \%$ of the surveyed islands exhibited only one to five species, $45 \%$ harboured more than five species, and three islands contained only 7, 8 and 10 species; in contrast, continuous forest sites in the mainland retained between 11 and 20 species.

Considering only islands, there was no significant species-area relationship $(\mathrm{SAR})$ on the basis of a semi-log model $\left(\mathrm{R}^{2}\right.$ adj $\left.=0.000, \mathrm{P}=0.471\right)$. Island distance to the nearest mainland area also failed to explain harvestmen species richness $\left(R^{2}\right.$ adj $=0.000$, $\mathrm{P}=0.835)$. Similar patterns were also observed for species composition, with neither island size $\left(\mathrm{R}_{\text {adj }}^{2}=0.001, \mathrm{P}=0.326\right)$ nor island isolation $\left(\mathrm{R}_{\text {adj }}^{2}=0.000, \mathrm{P}=0.422\right)$ significantly affecting the first NMDS axis. Island size and isolation also failed to affect patterns of overall harvestmen abundance within sites (Area $-\mathrm{R}_{\text {adj }}^{2}=0.000, \mathrm{P}=0.423$; Isolation $-\mathrm{R}^{2}$ adj $=0.000, \mathrm{P}=0.363$ ). The species composition of harvestmen (Fig. 3) differed between islands and mainland continuous forest sites (PERMANOVA: $F=4.76$, 
$\mathrm{P}=0.01)$. None of compositional metrics were affected by distance $(\mathrm{MRM} r=0.24, \mathrm{p}=$ $0.180)$.

When all explanatory variables were also incorporated into the models, GLMs showed that landscape-scale forest cover alone was included in the best model explaining patterns of local species composition (Table 2; Fig. 4). Considering species richness, however, neither of the local habitat nor landscape variables were significant predictors in the 'best' model. In contrast, number of trees, forest cover, island size, abundance of palm trees, and the amount of fallen woody stems were all significant predictors of harvestmen abundance (Table 2).

\section{Discussion}

As far as we are aware, this is the first study to examine harvestmen responses to habitat insularization induced by a large dam within tropical forests. Islands harboured fewer species than mainland continuous forest sites, and exhibited a simplified species composition. Contrary to our expectations, island area and isolation did not predict patterns of species richness, as predicted by the equilibrium theory of island biogeography (MacArthur \& Wilson, 1967). However, a set of local, patch and landscape variables was included in the best models predicting species composition and abundance. Due to the detrimental impacts of hydroelectric dams on forest biota, we provide additional evidence that these infrastructure projects are far from the 'green energy' sources they are often considered to be (Gibson et al., 2017), and propose conservation actions to enhance the long term persistence of harvestmen assemblages and other arthropods within reservoir areas.

\section{Main drivers of harvestmen assemblage structure}

Contrary to our expectations, none of the local, patch and landscape variables were included in the best models explaining harvestmen species richness on islands. In the Balbina archipelagic landscape, island size was a strong positive predictor of species richness in other taxonomic groups - including birds (Aurélio-Silva et al., 2016), small mammals (Palmeirim et al. 2018) and large mammals (Benchimol \& Peres, 2015a). Although the species-area relationship is one of the few ironclad rules in ecology (Mathews et al. 2016), we found that area failed in explaining richness patterns for harvestmen assemblages, the absence of this relationship has been documented before 
for this group in Amazonian upland forest sites where microhabitat structure and availability per unit area also explained patterns of harvestmen species composition but not species richness in harvestmen assemblages (Colmenares et al., 2016). The same pattern was also found for other arthropods, such as macro-moth communities in temperate woodland countryside landscapes, although in that case habitat amount, rather than patch size and isolation were the main drivers of species richness (Merckx et al., 2019), both however have not explained it for harvestmen either. Harvestmen species richness may not be responding to any of the most common predictor variable collectively but individually some severe richness reduction occurred in the fragmented Island mosaic in Balbina lake, on the other hand there are some species apparently benefiting of the fragmentation effects promoted by the dam.

Although the species area relationship is one of the most known and well documented patterns in ecology our results shown that considering SAR as more important or only considering SAR may possibly mislead or obfuscate the main conclusions of the impacts of forest fragmented areas. There were marked shifts in species composition, and we detected a significant species turnover between islands and continuous forest sites, indicating pervasive changes of harvestmen species assemblages on islands after 20 years of isolation. Because the continuous forest sites are clustered far from the islands (Fig. 4), it is possible that some differences in species composition were simply caused by the geographical separation of these areas. However, it is unlikely that such a strong difference in species composition as shown (Fig. 5) could be entirely caused by distance-decay. Both forest cover and fallen woody stems were the main joint drivers structuring the composition of harvestmen species on islands. Given that the presence of large canopy trees and palm tree architecture provide more available habitat, these variables have been considered as a good proxy of harvestmen diversity in studies at upland Amazonian forests (Colmenares et al., 2016, Porto et al., 2016, Tourinho et al., 2014).

Additionally, habitat quantity and quality have been equally proposed as robust predictors of harvestmen species composition in a fragmented Atlantic forest landscape (Bragagnolo et al., 2007), providing more evidence of the importance of habitat quality in maintaining tropical harvestmen assemblages. Fallen woody stems are often considered as one of the most likely microhabitats to contain harvestmen, especially aggregations during diurnal periods (Pinto-da-Rocha et al. 2007), yet the associations 
between harvestmen assemblages and this particular microhabitat have not been properly quantified in tropical forests. In fact, higher density of fallen woody stems may increase habitats favoured by harvestmen, providing ideal microclimatic conditions of humidity and temperature required for the development of some species (Mestre \& Pinto-da-Rocha, 2004; Curtis \& Machado, 2007; Proud et al., 2012). Notably, this was an important variable structuring both harvestmen species composition and abundance across the Balbina islands. A positive association between harvestmen assemblages and fallen logs have not always been detected in undisturbed tropical forests, but this microhabitat type is often associated with some specific harvestmen species in Amazonian forests (Colmenares et al., 2016).

The amount of landscape-scale forest cover was another variable retained in the best model influencing havestmen composition on Balbina islands. This variable was also included in the best model affecting patterns of abundance. The role of total amount of surrounding suitable habitat area is widely recognized in determining local patterns of diversity (Andrén, 1994), and has been considered as a good proxy of habitat loss (Fahrig, 2003, 2013). Indeed, several studies in the Atlantic forest has showed the paramount importance of forest cover in predicting abundance patterns of insects (Morante-Filho et al., 2016) and vertebrates (Lira et al., 2012; Morante-Filho et al., 2015)

The amount of surrounding forest cover, number of palm and number of trees, fallen woody stems and island size explained harvestmen abundance patterns at the Balbina islands. Thus, larger islands harbouring higher forest basal area, particularly arborescent palms, are necessary to sustain larger populations of harvestmen species on islands. In fact, tree microhabitats harboured the most diverse and abundant harvestmen assemblages, and was the only variable positively associated with harvestmen abundances in a Central Amazonian forest site distant $\sim 190 \mathrm{~km}$ from Balbina (Colmenares et al., 2016).

Overall harvestmen abundance declined in response to local, patch and landscape-scale variables on surveyed islands. For instance, number of trees was a strong predictor of harvestmen abundance patterns. Arboreal trees are highly sensitive to forest fragmentation, with many trees species becoming rapidly extirpated from small forest remnants (Silva \& Tabarelli 2000; Laurance et al. 2006; Tabarelli, Peres \& Melo 
2012). This effect is potentially stronger on islands created by hydroelectric dams, with a rapid decay in the floristic diversity detected on small Balbina islands (Benchimol \& Peres, 2015b). Fallen woody stems on small Balbina islands - where tree habitat diversity has been severely reduced - may therefore function as important alternative microhabitats for harvestmen assemblages. Therefore, most islands created by the Balbina dam are likely unfavourable for the long-term persistence of viable harvestmen populations, which may lead to local extinctions, creating a set of species-poor islands. On the other hand, species associated with fallen woody stems may benefit from tree mortality induced by high rates of windfalls on small islands (Benchimol \& Peres 2015b), thereby becoming highly successful species in this archipelago (two Manaosbiidae and two Stygnus-Stygnidae species).

The depauperate tree species composition on most Balbina islands has been detected in a previous study showing that the rapid decay in tree diversity across the archipelago is promoted by edge effects, including edge-related fires and wind-blown tree falls (Benchimol \& Peres, 2015b). Although the influence of habitat quantity and structure over the abundance and spatial distribution of harvestmen has not been sufficiently explored, harvestmen have a close relationship with vegetation structure, mostly trees and palms, and microclimate which create environmental gradients affecting their species composition (Colmenares et al., 2016). Islands containing higher densities of mature trees and palms harbour distinct assemblages and provide the appropriate microclimatic conditions to retain harvestmen species. Harvestmen and other arachnids, such as spiders, are associated with tree bole surface area, particularly those providing the appropriate bark properties, which are important niches for resting, foraging (Southwood, 1978; Pinzón \& Spence, 2010), and appropriate substrates for daytime camouflage and web attachment (Messas et al., 2014).

\section{Species-specific responses to landscape insularization}

According to several other studies, the diversity of harvestmen recorded on the islands was low (Pinto-da-Rocha \& Bonaldo, 2006; Bonaldo et al., 2009; Colmenares et al., 2016; Tourinho et al., 2014, 2018, Porto et al., 2016). The small number of species detected per island also reinforces diversity impoverishment in forest fragments, as suggested for the Atlantic Forest (Bragagnolo et al., 2007) and temperate forests (Černecká. et al., 2017, Mihál \& Černecká, 2017). Indeed, more than half of the 
sampled islands exhibited only one to five species, whereas mainland sites retained 1120 species, exhibiting a similar pattern obtained in other Amazonian sites (Tourinho et al. 2011, 2014, 2018, Porto et al. 2016, Bonaldo et. al, 2009). The intense sampling effort applied in this study - 20 islands (4 replicates each) - is also an indicative of islands impoverishment (160 hours sampling). As an example, species richness recovered in only 6 controls in mainland areas, with a much inferior effort (48 h) rendered 22 species which may be considered comparable to other areas in the Amazon, and new additions in numbers of sites sampled would certainly increase the number of species sampled as well.

Interestingly, the number of exclusive species retained on islands (9) was not as low as expected, but still lower than the number of species exclusively recorded at mainland forest sites, even if they had been allocated a lower sampling effort (13). However, looking into these results we note that exclusive species sampled on islands are minute harvestmen species and/or specimens, except one. They are members of Agoristenidae, tiny Stygnidae genera, but mostly members of families of Zalmoxoidea and Samooidea (Fig. 2) that inhabit leaf litter layers and other cryptic environments in the Amazon forest, for which little collecting effort had been invested in this study. Given that we sampled few individuals occasionally, mostly singletons or doubletons, the lack of records in mainland sites can also be an artefact, so we would expect to enhance the records of these specimens sifting leaf litter in mainland sites, as happened before in other Amazonian sites (Bonaldo et al. 2009, Tourinho et al. 2014).

Conversely, Cosmetidae and Sclerosomatidae species seem to be highly responsive to forest alteration and fragmentation. We did not record any of the six mainland Sclerosomatidae species on islands, and from the four species of Cosmetidae, we sampled just 7 specimens of Eucynortella aff. duapunctata Goodnight \& Goodnight, 1943 on only five islands (Fig. 2), contrasting with 47 specimens sampled across all 5 mainland sites. Those results are quite uncommon because E. aff. duapunctata followed by other species of the same genus and at least one or two species of Gagrellinae (Sclerosomatidae) are the most common, widespread and abundant species (Tourinho et al. 2014, 2018, Porto et al., 2016). Additionally, Cosmetidae, Sclerosomatidae are the top most diverse and abundant species/families in virtually all investigated sites in the Amazon (Bonaldo et al., 2009, Tourinho et al., 2018, Tourinho et al., 2014, Porto et. 
al., 2016) and our results in mainland followed this pattern as expected in undisturbed areas.

The majority of harvestmen species are highly endemic and have poor disperser skills, tending to move a few dozen meters during their lives (Mestre \& Pinto-da-Rocha, 2004, Pinto-da-Rocha et al., 2007). Exceptions are some Eupnoi species, such as species of Sclerosomatidae, which exhibited higher vagility. Species of harvestmen are generally predators, and most of the species of Sclerosomatidae observed in the Amazon were predating on small insects (e.g. flies and beetles, Tourinho person. comm.), being more susceptible to habitat and other environmental structure and size than other trophic groups (Srivastava et al. 2008, Villanueva-Bonilla et al. 2017). Possibly they possess a closer relationship with the structure and architecture of some specific species of trees, palms and/or other plants in the Amazon forests, and because of their physiology and strong associations with plant microhabitat, it might be probably difficult for harvestmen species from forested environments in the Amazon to succeed in colonizing highly disturbed island areas in Balbina lake.

\section{Conclusions}

Arthropods play vital roles in various ecosystem functions, and are widely considered as good indicators of overall biodiversity and forest integrity (Maleque et al., 2006). Among the Arachnida, harvestmen comprise the third most diverse order (Shultz \& Pinto-da-Rocha, 2007), exhibiting high sensitivity to habitat reduction and edge effects (Bragagnolo et al. 2007). Our study shows that forest loss significantly affected the species composition of harvestmen assemblages across islands created by a major hydroelectric dam, following 20 years of isolation. Although total species richness did not respond to local, patch and landscape variables, the assemblage structure of harvestmen was severely affected by landscape-scale forest amount which was probably affected by the rapid decay in tree diversity on most small forest islands in this reservoir (Benchimol \& Peres, 2015b). This result demonstrates that harvestmen species composition exhibits a turnover pattern among islands mostly driven by landscape forest amount, therefore indicating that both islands embedded within greater and lower amount of forest cover are important to ensure high diversity of faunal groups. Although 
we were unable to classify species as generalist and specialist groups, it is expected that islands surrounded by large amount of forest cover are harboring more specialist groups (see Morante-Filho et al., 2015). Thus, islands surrounded by high amount of forest must be maintained to preserve sensitive species. We also presume that the rapid decay in tree diversity on most small forest islands in this reservoir (Benchimol \& Peres, 2015b), which in turn directly affects habitat quality, is affecting harvestmen species composition. Given the pivotal importance of microhabitat quality for harvestmen (Bragagnolo et al., 2007), we expect that a reduction in environmental heterogeneity is directly impacting several harvestmen species. Observed shifts in community structure can potentially lead to an impoverished forest functioning and integrity, especially because changes in tree diversity in insular forests at Balbina are expected to be aggravated in the future (Benchimol \& Peres 2015b). We therefore provide additional evidence of the detrimental ecological consequences of dam impoundments on biodiversity, emphasizing that dams are far from the often hailed green sources of energy (Gibson et al., 2017). For existing dams, we recommend that well-preserved and large forest islands, surrounded by large amounts of forest cover, should be protected in the long-term. This can buffer the effects of natural forest disturbance and preclude rapid decay in tree communities, contributing therefore to maintain high diversity of several faunal groups, including harvestmen and other arthropods.

\section{Acknowledgments}

Adriano Kury provided key assistance with harvestmen type specimens, Pio Colmenares identified Laniatores specimens and tabulated species data; their support have made this work possible. Regiane Saturnino kindly made available local environmental data collected for her master thesis during arachnids sampling across the Balbina islands. We thank Ricardo Vicente and Thiago Izzo for providing some of the $\mathrm{R}$ scripts used in this paper to run some of the analysis. This study was supported by Beca Program, from International Institute of Education of Brazil Programa Beca \#B/2005/02/BMP/14, Reserva Biológica do Uatumã and a PNPD grant from the Coordination of Improvement of Higher Education Personnel - CAPES to ALT.

\section{Authors Contribution}


ALT collected data, performed the spatial correlation analysis and wrote the first drafts of the manuscript; ALT and WP identified species, DST ran most of the analysis, made figures, tables and described these procedures in Methods section. MB ran analysis and actively participated in the subsequent writing rounds. ALT, DST and MB conceptualized the study. $\mathrm{CP}$ detailed checked the results. All the authors discussed the results, read and equally contributed to the subsequent versions of the manuscript.

\section{References}

Acosta, L.E., Pérez-González A. \& Tourinho A.L. (2007) Methods for taxonomic study. Harvestmen: The Biology of Opiliones. (ed. by Pinto-da-Rocha R., Machado G. \& Giribet G.), pp. 494-510. Harvard University Press, Cambridge, Massachusetts.

Alho, C.J.R. (2011) Environmental effects of hydropower reservoirs on wild mammals and freshwater turtles in Amazonia: a review. Oecologia Australis, 15(3), 593-604.

Almeida, C.A., Valeriano, D.M.; Escada, M.I.S. \& Rennó, C.D. (2010) Estimativa de área de vegetação secundária na Amazônia Legal brasileira. Acta Amazonica, 40, 289302.

Andrén, H. (1994) Effects of habitat fragmentation on birds and mammals in landscapes with different proportions of suitable habitat: a review. Oikos, 71(3), 355-366. doi: $10.2307 / 3545823$

Aurélio-Silva, M., Anciães, M., Henriques, L.M.P., Benchimol, M. \& Peres, C.A. (2016) Patterns of local extinction in an Amazonian archipelagic avifauna following 25 years of insularization. Biological Conservation, 199, 101-109. https://doi.org/10.1016/j.biocon.2016.03.016

Barton, K. (2018) MuMIn: Multi-Model Inference. R package version 1.40.4.

Benchimol, M. \& Peres, C.A. (2015a) Widespread forest vertebrate extinctions induced by a mega hydroelectric dam in lowland Amazonia. PLoS ONE, 10, e0129818. https://doi.org/10.1371/journal.pone.0129818

Benchimol, M. \& Peres, C.A. (2015b) Edge-mediated compositional and functional decay of tree assemblages in Amazonian forest islands after 26 years of isolation. Journal of Ecology, 103, 408-420. 
Benchimol, M. \& Peres, C.A. (2015c) Predicting local extinctions of Amazonian vertebrates in forest islands created by a mega dam. Biological Conservation, 187, 6172.

Benchimol, M., Mariano-Neto, E., Faria, D., Rocha-Santos, L., de Souza Pessoa, M., Gomes, F.S., Talora, D.C. \& Cazetta, E. (2017) Translating plant community responses to habitat loss into conservation practices: forest cover matters. Biological conservation, 209, 499-507.

Benchimol, M. \& Venticinque, E.M. (2014) Responses of Primates to Landscape Change in Amazonian Land-bridge islands-a Multi-scale Analysis. Biotropica, 56(4), 470-478. https://doi.org/10.1111/btp.12122.

Bobrowiec, P.E.D. \& Tavares, V.C. (2017) Establishing baseline biodiversity data prior to hydroelectric dam construction to monitoring impacts to bats in the Brazilian Amazon. PLoS One, 12(9), e0183036. doi:10.1371/journal.pone.0183036

Bonaldo, A.B., Carvalho, L.S., Pinto-da-Rocha, R., Tourinho, A., Miglio, L.T., Candiani, D.F., Lo-Man-Hung, N.F., Abrahim, N., Rodrigues, B.V.B, Brescovit, A.D., Saturnino, R.F., Bastos, N.C., Dias, S.C., Silva, B.J.F., Pereira-Filho, J.M.B., Rheims, C.A., Lucas, S.M., Polotow, D., Ruiz, G.R.S. \& Indicatti, R.P. (2009) Inventário e história natural dos aracnídeos da Floresta Nacional de Caxiuanã. Caxiuanã: Desafios Para a Conservação De Uma Floresta Nacional Na Amazônia (ed. by Lisboa, P.L.B.), pp. 545-588. Museu Paraense Emílio Goeldi, Belém, Pará.

Bragagnolo, C., Nogueira, A.A., Pinto-da-Rocha, R. \& Pardini, R. (2007) Harvestmen in an Atlantic forest fragmented landscape: evaluating assemblage response to habitat quality and quantity. Biological Conservation, 139, 389-400.

Bueno, A.S. \& Peres, C.A. (2019) Patch-scale biodiversity retention in fragmented landscapes: Reconciling the habitat amount hypothesis with the island biogeography theory. Journal of Biogeography, 46, 621-632.

Burnham, K.P. \& Anderson, D.R. (2002) Model Selection and Multimodel Inference: a Practical Information-theoretical Approach. Springer, New York City, New York.

Carvalho, L.S., Gomes, J.O., Neckel-Oliveira, S. \& Lo-Man-Hung, N.F. (2012) Microhabitat use and intraspecific associations in the whip spider Heterophrynus 
longicornis (Arachnida: Amblypygi) in forest fragments formed by the Tucuruí Dam lake, Pará, Brazil. Journal of Natural History, 46, 1263-1272. https://doi.org/10.1080/00222933.2012.654515

Colmenares P.A, Baccaro, F.B. \& Tourinho, A.L. (2016) Assessing the Relationship of Vegetation Structure and Harvestmen Assemblage in an Amazonian Upland Forest. bioRxiv. doi:10.1101/078220

Curtis, D.J. \& Machado, G. (2007) Ecology. Harvestmen: The Biology of Opiliones (ed. by Pinto-da-Rocha, R., Machado, G. \& Giribet, G.), pp. 280-308. Harvard University Press, Cambridge, USA.

Černecká L'., Mihál I. \& Jarčuška B. (2017) Response of ground-dwelling harvestman assemblages (Arachnida: Opiliones) to European beech forest canopy cover. European Journal of Entomology, 114, 334-342.

Dai, A., Trenberth \& K. E. (2002) Estimates of Freshwater Discharge from Continents: Latitudinal and Seasonal Variations, Journal of Hydrometeorology, 3(6), 660-687. doi:10.1175/1525-7541(2002)003<0660:EOFDFC>2.0.CO;2

Dormann, C.F., Elith, J., Bacher, S., Buchmann, C., Carl, G., Carré, G., García Marquéz, J.R., Gruber, B., Lafourcade, B., Leitão, P.J., Münkemüller, T., McClean, C., Osborne, P.E., Reineking, B., Schröder, B., Skidmore, A.K., Zurell, D. \& Lautenbach, S. (2013) Collinearity: a review of methods to deal with it and a simulation study evaluating their performance. Ecography, 36, 027-046.10.1111/j.16000587.2012.07348.x

ECOA Ecologia em Ação. (2018) International Rivers and Fundacion Proteger, Dams in Amazonia. [WWW document]. <http://www.dams-info.org/en> $3^{\text {rd }}$ February 2018.

Eletronorte, Ibama. (1997) Plano de Manejo Fase I Reserva Biológica Uatumã._ [WWW document].<http://www.icmbio.gov.br/portal/images/stories/docs-planos-demanejo/rebio_uatuma_pm.pdf $>3^{\text {rd }}$ February 2018.

ESRI. (2016) ArcGIS Desktop: Release 10. Environmental Systems Research Institute, Redlands, CA. 
Esselman, P.C. \& Opperman, J.J. (2010) Overcoming information limitations for the prescription of an environmental flow regime for a central American river. Ecology and Society, 15(1), 6.

Fahrig, L. (2003) Effects of habitat fragmentation on biodiversity. Annual Review of Ecology, Evolution, and Systematics, 34, 487-515.

Fahrig, L. (2013) Rethinking patch size and isolation effects: the habitat amount hypothesis. Journal of Biogeography, 40, 1649-1663

Fearnside, P.M. (2016) Environmental and Social Impacts of Hydroelectric Dams in Brazilian Amazonia: Implications for the Aluminum Industry. World Development, 77, 48-65. https://doi.org/10.1016/j.world dev.2015.08.015

Franken, E.P., Baccaro, F. \& Gasnier, T.R. (2013) Is there a refuge for ants in litter accumulated at the base of Attalea attaleoides (Barb. Rodr.) Wess. Boer (Arecaceae)? Entomotropica, 28, 27-37.

Gibson, L., Wilman, E.N. \& Laurance, W.F. (2017) How Green is 'Green'Energy? Trends in Ecology \& Evolution, 32(12), 922-935 https://doi.org/10.1016/j.tree.2017.09.007

Heiberger, R.M. (2016) HH: Statistical analysis and data display: Heiberger and Holland. R package version. 3,1-31.

Kury, A.B. (2003) Annotated catalogue of the Laniatores of the New World (Arachnida, Opiliones). Revista Ibérica de Aracnología, 1, 1-337.

Laurance, W. F., Nascimento, H.E.M., Laurance, S.G., Andrade, A.C., Fearnside, P.M., Ribeiro, J.E.L. \& Capretz, R.L. (2006) Rain forest fragmentation and the proliferation of successional trees. Ecology, 87(2), 469-82. https://doi.org/10.1890/05-0064

Lees, A.C., Peres, C.A., Fearnside, P.M., Schneider, M. \& Zuanon, J.A. (2016) Hydropower and the future of Amazonian biodiversity. Biodiversity and conservation, 25(3), 451-466. https://doi.org/10.1007/s10531-016-1072-3

Liermann, C.R., Nilsson C., Robertson J. \& Ng, R.Y. (2012) Implications of dam obstruction for global freshwater fish diversity. Bioscience, 62, 539-548. 
Lira, P.K., Ewers, R.M., Banks-Leite, C., Pardini, R. \& Metzger, J.P. (2012) Evaluating the legacy of landscape history: extinction debt and species credit in bird and small mammal assemblages in the Brazilian Atlantic Forest. Journal of Applied Ecology, 49(6), 1325-1333.

MacArthur, R. H. \& Wilson, E. O. (1967) The Theory of Island Biogeography. Princeton Univ. Press, Princeton, New Jersey.

Maleque, M.A., Ishii, H.T. \& Maeto, K. (2006) The use of arthropods as indicators of ecosystem integrity in forest management. Journal of Forestry, 104(3), 113-117.

Matthews, T. J., Guilhaumon, F., Triantis, K.A., Borregaard, M.K. \& Whittaker, R.J. (2016) On the form of species-area relationships in habitat islands and true islands. Global Ecology and Biogeography, 25(7), 847-858. https://doi.org/10.1111/geb.12269

McGarigal, K., Cushman, S.A. \& Ene, E. (2012) F FRAGSTATS v4: Spatial Pattern Analysis Program for Categorical and Continuous Maps. [WWW document]. <http://www.umass.edu/landeco/research/fragstats/fragstats.html>. January 2014).

Melo, T.S., Peres, M.C.L, Andrade, A.R.S., Oliveira, M.L.T. \& Tinoco, M.S. (2015) Artrópodes Terrestres no Licenciamento Ambiental: Um Modelo Para Utilização Por Empresas De Consultoria. Latin American Journal of Business Management, 6(3), 126144.

Merckx, T., Miranda, M.D. \& Pereira, H.M. (2019) Habitat amount, not patch size and isolation, drives species richness of macro-moth communities in countryside landscapes. Journal of Biogeography, 46(5): 956-967. https://doi.org/10.1111/jbi.13544

Messas, Y., Souza, H., Gonzaga, M. \& Vasconcellos-Neto, J. (2014) Spatial distribution and substrate selection by the orb-weaver spider Eustala perfida Mello-Leitão, 1947 (Araneae: Araneidae). Journal of Natural History, 48, 2645-2660.

Mestre, L.A.M. \& Pinto-da-Rocha, R. (2004) Population biology of the harvestmen Ilhaia cuspidata (Opiliones; Gonyleptidae) in an Araucaria Forest fragment (Curitiba Paraná, Brazil). The Journal of Arachnology, 32(2), 208-220. 
Mihál I. \& Černecká L'. (2017) Structure of harvestmen (Arachnida, Opiliones) communities in different, anthropically disturbed beech ecosystems (Western Carpathians, Slovakia). Vestnik zoologii, 51(3), 259-270.

Morante-Filho, J.C., Faria, D., Mariano-Neto, E. \& Rhodes, J. (2015) Birds in anthropogenic landscapes: the responses of ecological groups to forest loss in the Brazilian Atlantic Forest. PLoS One, 10(6), p.e0128923.

Morante-Filho, J.C., Arroyo-Rodríguez, V., Lohbeck, M., Tscharntke, T. \& Faria, D. (2016) Tropical forest loss and its multitrophic effects on insect herbivory. Ecology, 97(12), 3315-3325.

Nilsson, C., Reidy, C.A., Dynesius, M. \& Revenga, C. (2005) Fragmentation and Flow Regulation of the World's Large River Systems. Science, 308, 405-408. 10.1126/science. 1107887

Palmeirim A.F., Peres C.A. \& Rosas F.C.W. (2014) Giant otter population responses to habitat expansion and degradation induced by a mega hydroelectric dam. Biological Conservation, 174, 30-38. https://doi.org/10.1016/j.biocon.2014.03.015

Palmeirim, A.F., Benchimol, M., Vieira, M.V. \& Peres, C.A. (2018) Small mammal responses to Amazonian forest islands are modulated by their forest dependence. Oecologia, 187, 191-204. https://doi.org/10.1007/s00442-018-4114-6

Pinto-da-Rocha, R. (1994) A new species of Santinezia from central Amazonia, with systematic comments on the genus (Arachnida, Opiliones, Cranaidae). Andrias, 13, 2932.

Pinto-da-Rocha, R. (1996) Notes on Vima insignis Hirst , 1912 , revalidation of Trinella Goodnight \& Goodnight , 1947 with description of three new species(Arachnida, Opiliones, Agoristenidae). Revista Brasileira de Entomologia, 40, 315-323.

Pinto-da-Rocha, R. (1997) Systematic review of the Neotropical family Stygnidae (Opiliones, Laniatores, Gonyleptoidea). Arquivos de Zoologia, 33, 163-342.

Pinto-da-Rocha, R. (2004) A new species of Fissiphalliidae from Brazilian Amazon Rain Forest (Arachnida: Opiliones). Zootaxa, 6, 1-6. 
Pinto-da-Rocha, R. \& Bonaldo, A.B. (2006) A structured inventory of harvestmen (Arachnida , Opiliones ) at Juruti River plateau, State of Pará , Brazil. Revista Ibérica de Aracnología, 13, 155-162.

Pinto-da-Rocha, R., Machado, G \& Giribet, G. (2007) Harvestmen: The Biology of Opiliones. Harvard University Press. Cambridge, Massachusetts.

Pinzón, J. \& Spence, J. (2010) Bark-dwelling spider assemblages (Araneae) in the boreal forest: dominance, diversity, composition and life-histories. Journal of Insect Conservation, 14, 439-458.

Porto, W., Pequeno, P.A.L \& Tourinho, A.L. (2016) When less means more: Reduction of both effort and survey methods boosts efficiency and diversity of harvestmen in a $\begin{array}{lllll}\text { tropical forest. } & \text { Ecological } & \text { Indicators, } & \mathbf{6 9}, & 771-779 .\end{array}$ https://doi.org/10.1016/j.ecolind.2016.05.014

Proud, D.N., Felgenhauer, B.E., Townsend, V.R., Osula, D.O., Gilmore, W.O., Napier, Z.L. \& Van Zandt, P.A. (2012) Diversity and Habitat Use of Neotropical Harvestmen (Arachnida: Opiliones) in a Costa Rican Rainforest. ISRN Zoology, 2012, 1-16.

R Core Team (2016) R: A language and environment for statistical computing. R Foundation for Statistical Computing, Vienna, Austria. URL https://www.Rproject.org/.

Resende, L.P.A., Pinto-da-Rocha, R. \& Bragagnolo, C. (2012) Diversity of harvestmen (Arachnida, Opiliones) in Parque da Onça Parda , southeastern Brazil. Ilheringia, 102, 99-105.

RStudio Team (2016). RStudio: Integrated Development Environment for R. Boston, MA, http://www.rstudio.com/.

Shultz, J. W. \& Pinto-da-Rocha, R. (2007) Morphology and functional anatomy. Harvestmen: The Biology of Opiliones. (ed. by Pinto-da-Rocha, R., Machado, G. \& Giribet, G.), pp.14-61. Harvard University Press, Cambridge, Massachusetts.

Silva, J.M.C. \& Tabarelli, M. (2000) Tree species impoverishment and the future flora of the Atlantic forest of northeast Brazil, Nature, 404(6773), 72-74. DOI: $10.1038 / 35003563$ 
Southwood, L. (1978) Ecological Methods: with Particular Reference to the Study of Insect Populations. Chapman and Hall, London, U.K.

Srivastava, D.S., Trzcinski, M.K., Richardson, B.A. \& Gilbert, B. (2008) Why Are Predators More Sensitive to Habitat Size than Their Prey? Insights from Bromeliad Insect Food Webs. The American Naturalist, 172 (6), 761-771.

Storck-Tonon, D. \& Peres, C.A. (2017) Forest patch isolation drives local extinctions of Amazonian orchid bees in a 26 years old archipelago. Biological Conservation. 214, 270-277. https://doi.org/10.1016/j.biocon.2017.07.018

Sørensen, L.L., Coddington, J. \& Scharff, N. (2002) Inventorying and estimating subcanopy spider diversity using semiquantitative sampling methods in an afromontane forest. Environmental $\quad$ Entomology, 319-330. http://www.bioone.org/doi/abs/10.1603/0046-225X-31.2.319.

Tabarelli, M., Peres, C.A. \& Melo, P.L. (2012) The 'few winners and many losers' paradigm revisited: Emerging prospects for tropical forest biodiversity. Biological Conservation, 155, 136-140.

Tarli, V.D., Pequeno, P.A.C.L., Franklin, E., Oliveira, J. \& Guilherme, D.R. (2014) Multiple environmental controls on cockroach assemblage structure in a tropical rainforest. Biotropica, 46, 598-607. https://doi.org/10.1111/btp.12138

Terborgh, J., Lopez, L., Tello, J., Yu, D. \& Bruni, A.R. (1997) Transitory states in relaxing ecosystems of land bridge islands. Tropical forest remnants - Ecology, management and conservation of fragmented communities (ed. by Laurance, W.F. \& Bierregaard-Jr, R.O.), pp. 256-274. University of Chicago Press, Chicago, Illinois.

Tourinho, A.L., Saturnino, R., Dias, S.C., Guimarães, S., Assimen, S. \& Colmenares, P.A. (2011) Aranhas e opiliões da Reserva de Desenvolvimento Sustentável do Tupé, Amazonas - Brasil. BioTupé: Meio Físico, Diversidade Biológica e Sociocultural do Baixo Rio Negro, Amazônia Central (ed. by Santos-Silva, E.N. Scudeller, V.V. \& Cavalcanti, M.J.), pp. 271-289. Rizoma Editorial, Rio de Janeiro, Rio de Janeiro.

Tourinho, A.L., Lança, L.S., Baccaro, F.B. \& Dias, S.C. (2014) Complementarity among sampling methods for harvestman assemblages. Pedobiologia, 57(1), 37-45. https://doi.org/10.1016/j.pedobi.2013.09.007 
Tourinho, L.S., Dias, S.C., Lo Man Hung, N.F., Bonaldo, A.B., Pinto-da-Rocha, R. \& Baccaro, F.B. (2018) Optimizing survey methods for spiders and harvestmen assemblages in an Amazonian upland forest. Pedobiologia, 67, 35-44. https://doi.org/10.1016/j.pedobi.2017.11.002

Vasconcelos, H.L. (1990) Effect of litter collection by understory palms on the associated macroinvertebrate fauna in Central Amazonia. Pedobiologia, 34, 157-160.

Villanueva-Bonilla, G.A., Salomão, A.T. \& Vasconcellos-Neto, J. (2017) Trunk structural traits explain habitat use of a tree-dwelling spider (Selenopidae) in a tropical forest. Acta Oecologica, 85, 108-115. https://doi.org/10.1016/j.actao.2017.10.004

Yang, L.H. \& Gratton, C. (2014) Insect as drivers of ecosystem processes. Insect Science, 2, 26-32. https://doi.org/10.1016/j.cois.2014.06.004 


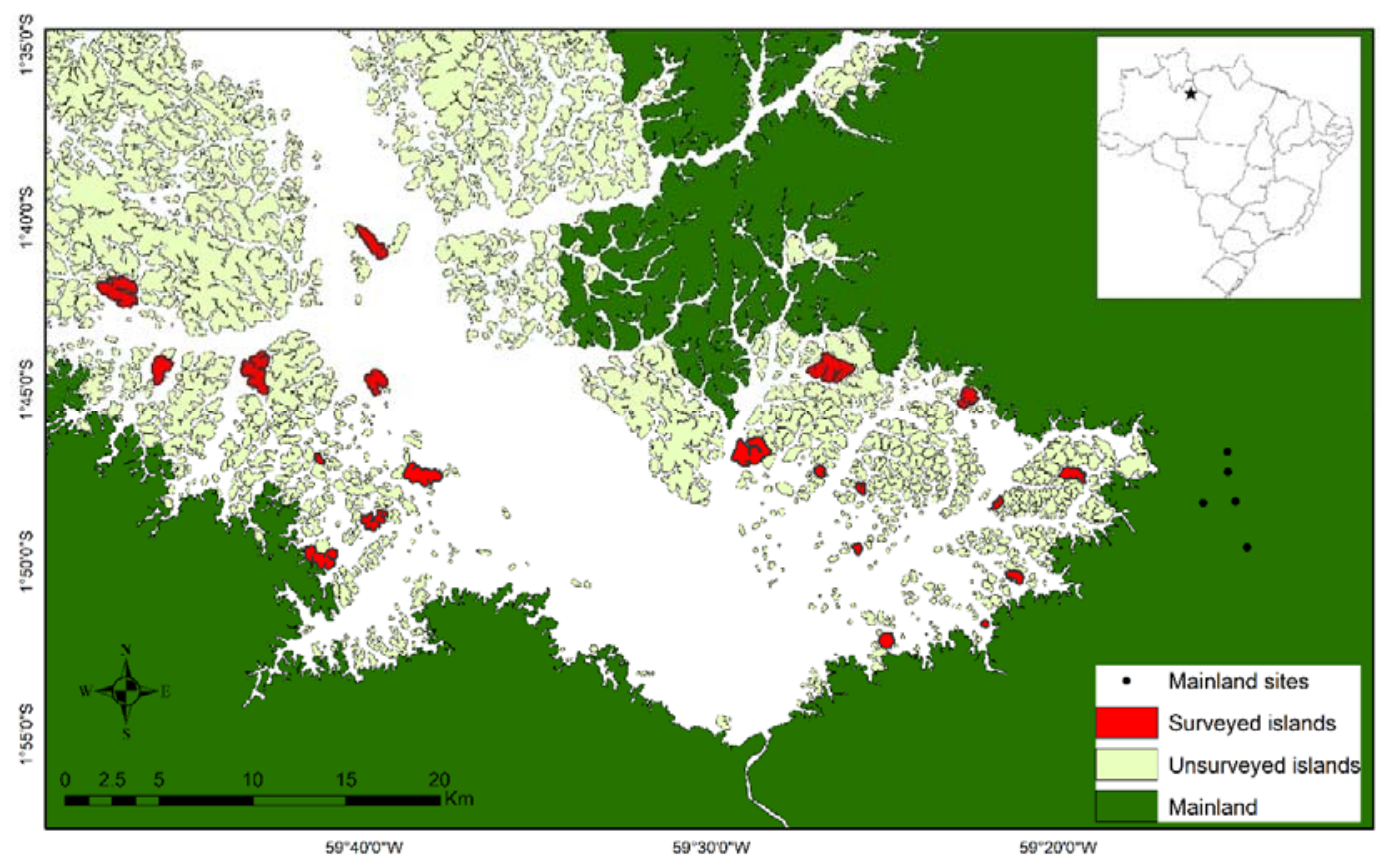

Figure 1. Spatial distribution of the 20 sampled islands (red) and 5 continuous forest sites (black circles) within the Balbina Hydroelectric Reservoir of central Brazilian Amazonia. 


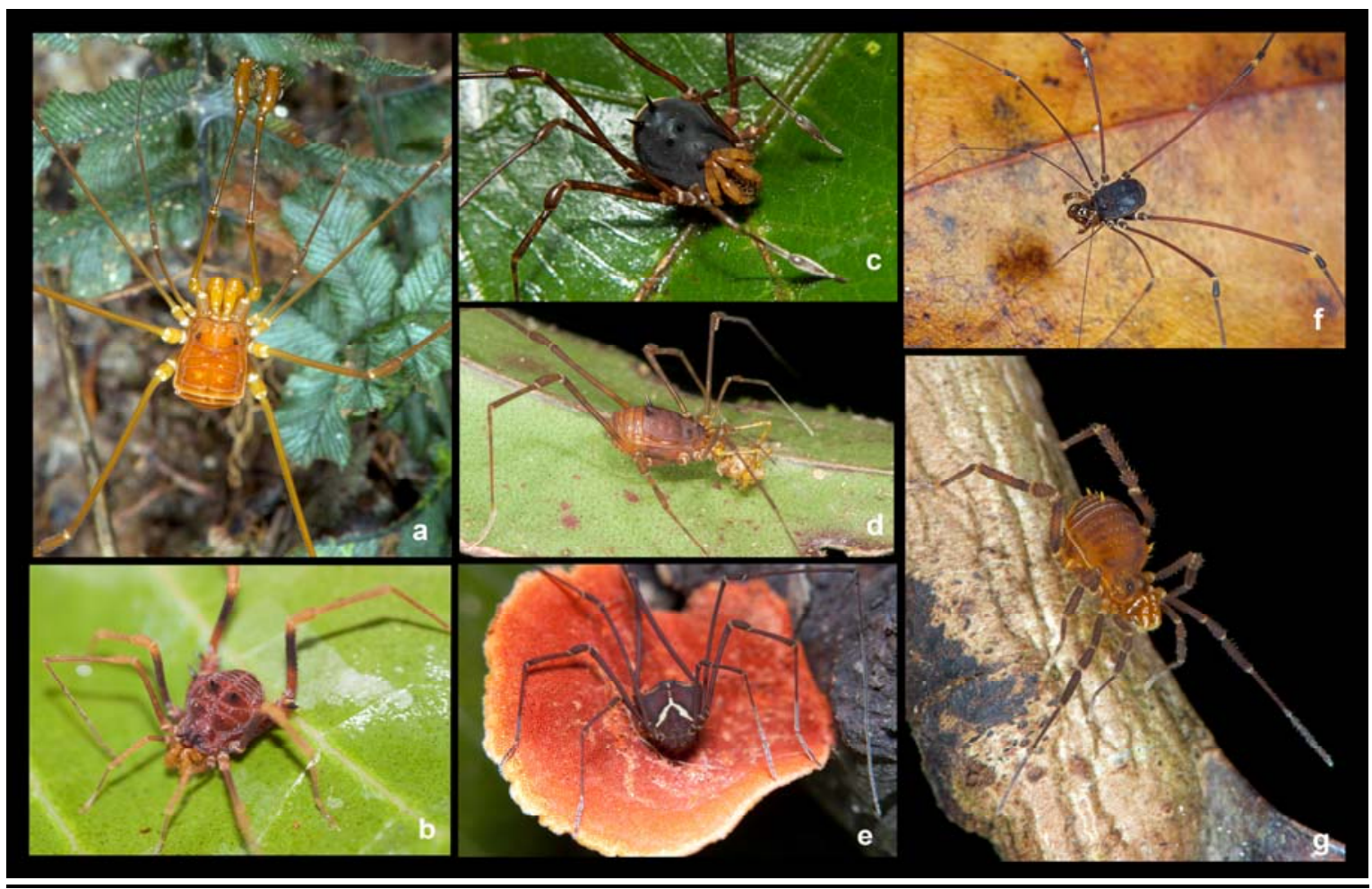

Figure 2. Some of the harvestmen species occurring in the Balbina Hydroelectric Reservoir - BHR and mainland: a) Male of Protimesius longipalpis (Stygnidae); b) Female of Amazochroma carvalhoi (Gonyleptidae), c) Male of Saramacia lucaseae (Manaosbiidae); d) Female of Stygnus pectinipes (Stygnidae); e) Male of Eucynortella aff. duapunctata (Cosmetidae); f) Male of Avima matintaperera (Agoristenidaae); g) Male of Fissiphallius martensi (Fissiphalliidae). 


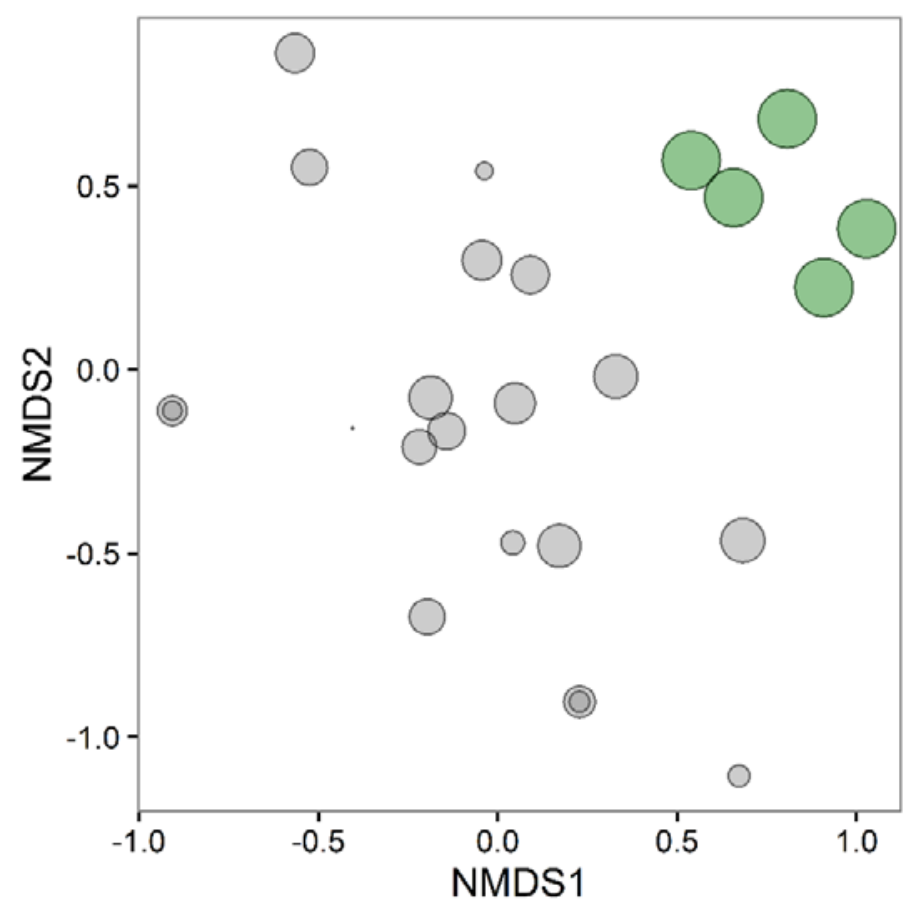

Figure 3. Nonmetric multidimensional scaling (NMDS) ordination using a Jaccard similarity matrix of harvestman composition in islands (gray circles) and mainland forest (green circles) sampled across the Balbina archipelago. Circles are sized in proportion to the log area of sampled sites. 


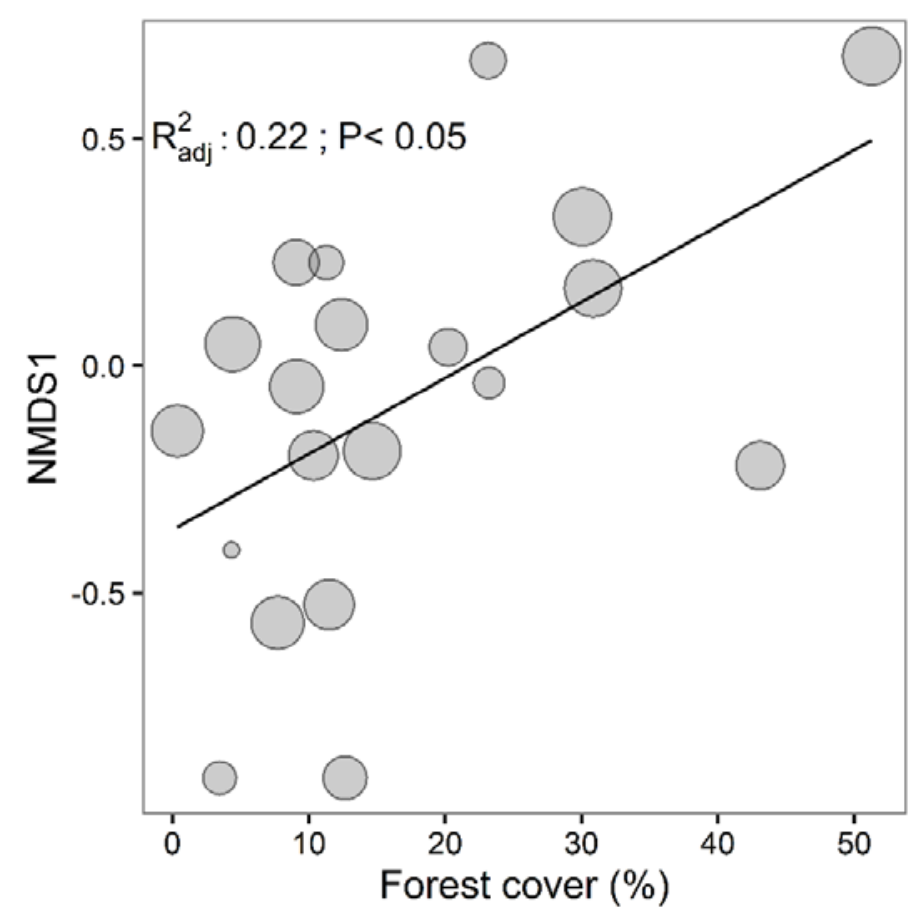

Figure 4. Relationships between the first non-metric multidimensional scaling (NMDS) axis representing the harvestmen species composition and forest cover within a $1000 \mathrm{~m}$ buffer. Circles proportional to the log area. 


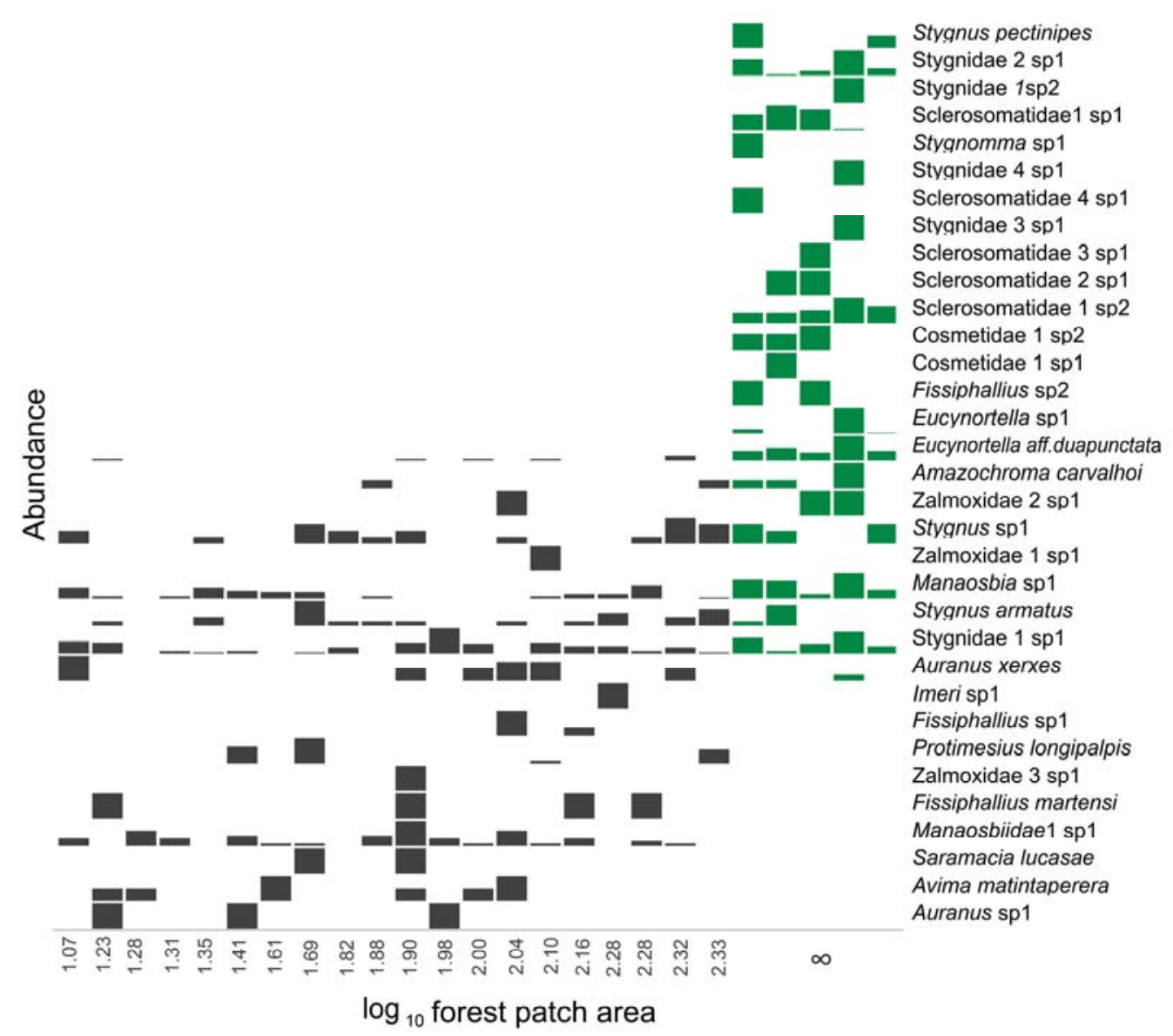

Figure 5. Site records of 31 harvestman species sampled across 25 trapping sites distributed throughout the Balbina Hydroelectric Reservoir. Species abundances within island and mainland forest sites are represented by gray and green rectangles, respectively. 
Table 1. Description of the explanatory variables used in the analyses.

\begin{tabular}{lll}
\hline Variable Codenames & Scale Description \\
name &
\end{tabular}

\begin{tabular}{lll}
\hline Litter depth $\quad$ litdepth $\quad$ Local & litter depth measured every $5 \mathrm{~m}$ along \\
& & the long by each transect.
\end{tabular}

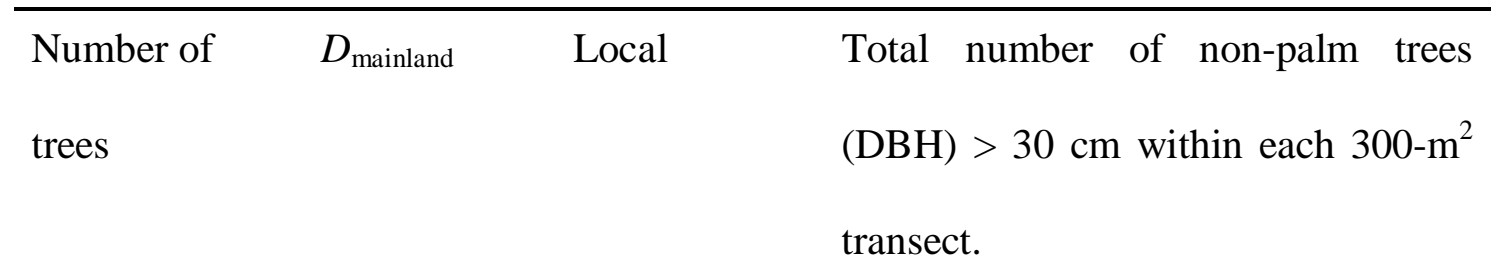

\begin{tabular}{|c|c|c|c|}
\hline Number of & palms & Local & Total number of palm trees $(\mathrm{DBH})>$ \\
\hline palm tree & & & $30 \mathrm{~cm}$ within each $300-\mathrm{m}^{2}$ transect. \\
\hline
\end{tabular}

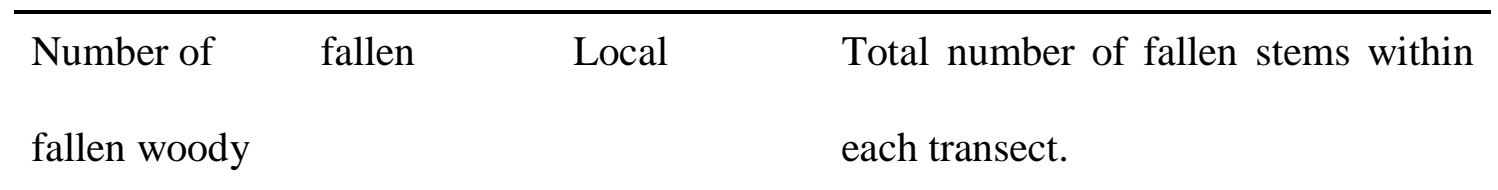

stems

\begin{tabular}{llll}
\hline Island size & area & Patch & $\begin{array}{l}\text { Total island area of each focal island. } \\
\text { In } \log _{10} \mathrm{x} \text { hectares. }\end{array}$ \\
& & \\
\hline Isolation & $D_{\text {mainland }}$ & Patch & Shortest linear distance from each \\
& & island to the nearest mainland. In \\
& & \\
\hline
\end{tabular}


meters.

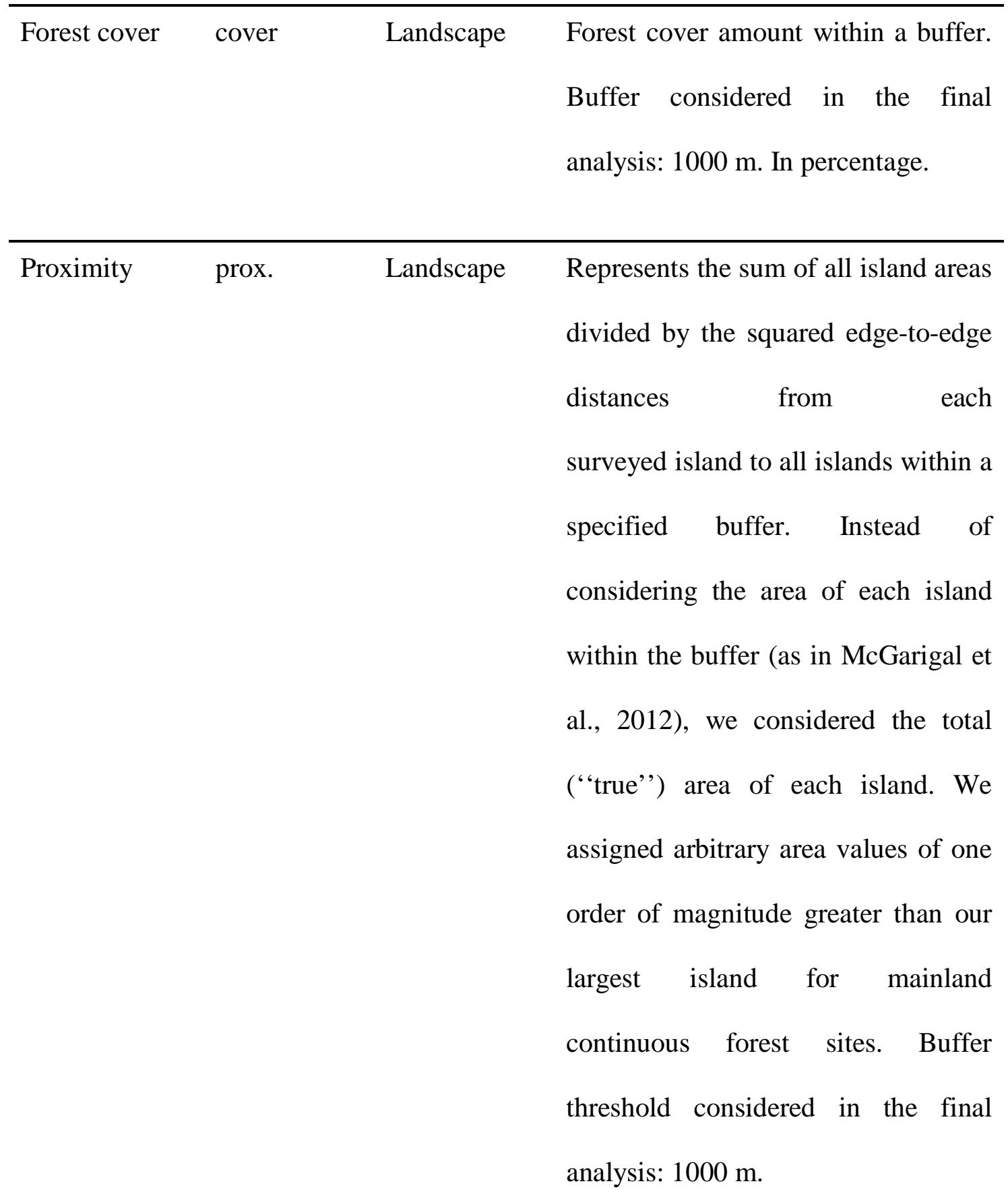


Table 2. Results of the Generalized Linear Models for the effects of island area $\left(\log _{10}\right)$, litter depth, fallen woody stems, palm trees, forest cover (buffer $1000 \mathrm{~m})$ and trees. Only the best models are shown $(\triangle \mathrm{AICc}<2)$. 


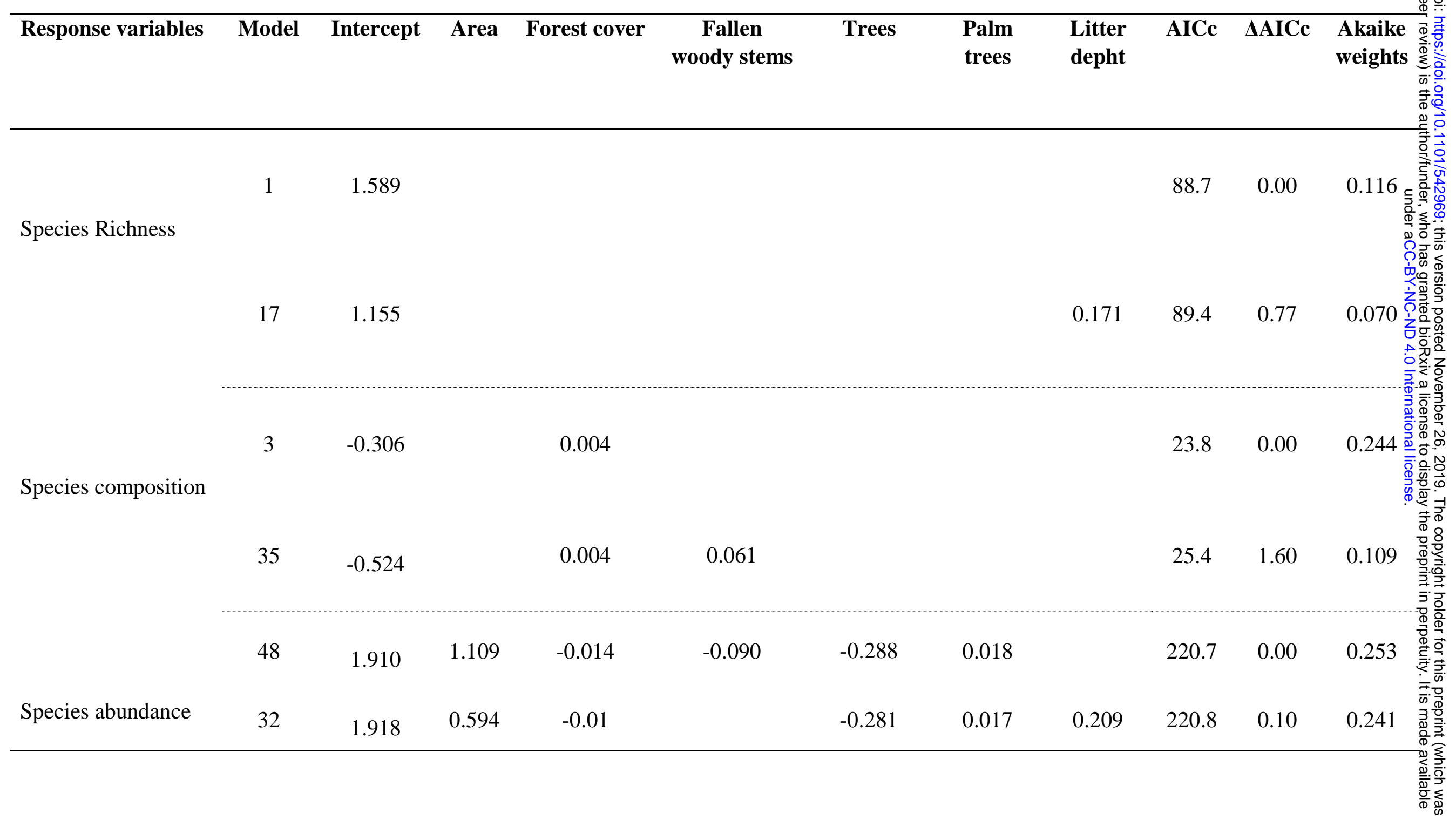


Table 3. Number of individuals of each harvestmen species recorded at the Balbina Hydroelectric Reservoir.

\begin{tabular}{ll}
\hline Species & Mainland Island Total
\end{tabular}

AGORISTENIDAE

Avima matintaperera (Pinto-da-Rocha, 1996)

$8 \quad 8$

COSMETIDAE

Cosmetidael sp.1

42

42

Cosmetidae1 sp.2

13

13

Eucynortella aff. duapunctata Goodnight \& 41

7

48

Goodnight, 1943

Eucynortella sp.1

FISSIPHALLIIDAE

Fissiphallius martensi Pinto-da-Rocha, 2004

Fissiphallius sp.1

4

4

Fissiphallius sp.2

2

2

GONYLEPTIDAE

Amazochroma carvalhoi (Mello-Leitão, 1941)

5

2

7

\section{MANAOSBIIDAE}


Manaosbia sp.1

Manaosbiidael sp.1

Manaosbiidae2 sp.1

Saramacia lucasae Jim \& Soares, 1991

SCLEROSOMATIDAE

Sclerosomatidae1 sp.1

Sclerosomatidae1 sp.2

Sclerosomatidae2 sp.1

Sclerosomatidae2 sp.2

Sclerosomatidae3 sp.1

Sclerosomatidae4 sp.1

STYGNIDAE
17

4

2

1

120

58

62

2

1

48

58

58

79

79

2

2

4

4

3

3

3

3

Auranus sp.1

Auranus xerxes Colmenares, Porto \& Tourinho, 20161

16

17

Imeri sp. 1

2

2

Protimesius longipalpis Roewer, 1943

88

100

Stygnus armatus Perty, 1833

48

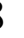

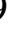

(n)

4

3

Stygnidae1 sp.1

14

18

32 
bioRxiv preprint doi: https://doi.org/10.1101/542969; this version posted November 26, 2019. The copyright holder for this preprint (which was not certified by peer review) is the author/funder, who has granted bioRxiv a license to display the preprint in perpetuity. It is made available under aCC-BY-NC-ND 4.0 International license.

Stygnus pectinipes (Roewer, 1943)

Stygnus sp.1

STYGNOMMATIDAE

Stygnomma sp.1

ZALMOXIDAE

Zalmoxidae1 sp.1

Zalmoxidae2 sp.1

Zalmoxidae3 sp.1
9

20

29

3

3

$1 \quad 1$

$\begin{array}{lll}2 & 1 & 3\end{array}$

$1 \quad 1$

Total

426

357

783 
Table S1. Number of individuals and species of harvestmen (Arachnida: Opiliones) sampled across 20 islands and 5 continuous forest sites across the Balbina Hydroelectric reservoir, Central Brazilian Amazonia.

\begin{tabular}{|c|c|c|c|c|c|}
\hline Site name & $\begin{array}{l}\text { Area } \\
\text { (ha) }\end{array}$ & UTM (X) & UTM (Y) & $\begin{array}{l}\text { Number of } \\
\text { species }\end{array}$ & $\begin{array}{l}\text { Number } 0 \\
\text { individuals }\end{array}$ \\
\hline Angelin & 67.44 & 240659 & 9801730 & 4 & 9 \\
\hline Cachoeira & 11.84 & 236641 & 9793981 & 5 & 20 \\
\hline Cipoal & 213.66 & 190871 & 9810812 & 5 & 17 \\
\hline Copa & 19.20 & 229635 & 9798056 & 4 & 13 \\
\hline Folharal & 102.30 & 192046 & 9806910 & 6 & 17 \\
\hline Galo de briga & 190.84 & 197368 & 9807612 & 3 & 9 \\
\hline Gemeas & 111.09 & 203037 & 9814880 & 6 & 38 \\
\hline Grande & 95.61 & 204026 & 9806251 & 6 & 48 \\
\hline Igarapé & 76.20 & 236013 & 9805808 & 4 & 10 \\
\hline Josue & 146.00 & 205982 & 9801462 & 6 & 24 \\
\hline Manoel gato & 194.59 & 223583 & 9802328 & 6 & 18 \\
\hline Massaranduba & 17.33 & 201171 & 9802527 & 7 & 25 \\
\hline Mucura & 22.57 & 229798 & 9800932 & 1 & 1 \\
\hline
\end{tabular}




\begin{tabular}{|c|c|c|c|c|c|}
\hline Neto & 41.59 & 237861 & 9796638 & 4 & 5 \\
\hline Palhal 1 & 20.78 & 237245 & 9800112 & 2 & 5 \\
\hline Palhal 2 & 25.81 & 227557 & 9801956 & 6 & 16 \\
\hline Pontal & 126.01 & 201747 & 9797850 & 8 & 27 \\
\hline Santa Luzia & 218.53 & 228363 & 9808143 & 3 & 4 \\
\hline Serrinha & 50.09 & 231033 & 9792680 & 2 & 2 \\
\hline $\mathrm{U}$ & 79.83 & 204181 & 9799600 & 10 & 49 \\
\hline Mainland 1 & $\infty$ & 251524 & 9801136 & 14 & 89 \\
\hline Mainland 2 & $\infty$ & 250493 & 9801920 & 11 & 55 \\
\hline Mainland 3 & $\infty$ & 247494 & 9800939 & 15 & 67 \\
\hline Mainland 4 & $\infty$ & 251567 & 9798861 & 20 & 168 \\
\hline Mainland 5 & $\infty$ & 251564 & 9797900 & 11 & 47 \\
\hline
\end{tabular}

